\title{
Structure, phase transformation, and hardness of NiTiHfNd alloys
}

\author{
Chunwang Zhao ${ }^{1,3} \cdot$ Shilei Zhao ${ }^{2,3}$
}

Received: 23 December 2020 / Accepted: 31 March 2021 / Published online: 17 April 2021

(c) The Author(s) $2021 \quad$ OPEN

\begin{abstract}
$\mathrm{Ni}_{50} \mathrm{Ti}_{29} \mathrm{Hf}_{21-x} \mathrm{Nd}_{x}\left(x=0,1,2\right.$ at.\%) and $\mathrm{Ni}_{50} \mathrm{Ti}_{29-x} \mathrm{Hf}_{21} \mathrm{Nd}_{x}(x=1,2$ at.\%) alloys were fabricated via arc melting. For the first time, the influence of $\mathrm{Nd}$ addition on structure, phase transformation, and hardness of NiTiHf alloy was investigated experimentally. It is found that the NiTiHfNd alloys consist of NiTiHf matrix and Nd-rich precipitates. $\mathrm{Ni}_{50} \mathrm{Ti}_{29} \mathrm{Hf}_{21}$ alloy demonstrates a martensitic transformation temperature as high as $314.1^{\circ} \mathrm{C}$, a thermal hysteresis as narrow as $37.7^{\circ} \mathrm{C}$, and a Vickers hardness as high as $500 \mathrm{HV}$. Nd addition obviously decreases the martensitic transformation temperature of NiTiHf alloys but still maintains a relatively narrow thermal hysteresis and a relatively high Vickers hardness compared with most other components of NiTiHf-based alloys.
\end{abstract}

Keywords $\mathrm{NiTiHfNd} \cdot$ Microstructure $\cdot$ Phase transformation $\cdot$ Hardness

\section{Introduction}

NiTi-based alloys can occur phase transformation between martensite and austenite, thus show so-called shape memory effect. Consequently, they have been applied in various fields, especially in mechanical engineering and medical applications [1]. It is well known that the phase transformation behaviors and the mechanical properties of NiTi-based alloys are strongly dependent on composition, alloying, precipitates, and heat treatment history [2]. Thus, alloying has been frequently utilized for tuning the phase transformation properties of NiTi-based alloys [3]. To date, transition metals such as Fe [4], $\mathrm{Cu}$ [5], Nb [6], Ta [7], $\mathrm{Zr}$ [8], Hf [9], Au [10], and Pd [11] have been adopted as alloying elements of NiTi-based alloys and the influence on the structure, phase transformation behavior, and mechanical properties have been comprehensively studied. These studies demonstrated that most transition metals lower the phase transformation temperatures, but some transition metals such as $\mathrm{Zr}, \mathrm{Hf}, \mathrm{Au}$, and $\mathrm{Pd}$ can increase the phase transformation temperatures to higher than $100^{\circ} \mathrm{C}[8]$ Therefore, NiTiZr, NiTiHf, NiTiAu, and NiTiPd are considered as candidates for high-temperature applications [2]. However, Au and Pd are noble metals, which largely limit the large-scale applications of NiTiAu and NiTiPd because of their high cost. Considering the high phase transformation temperatures and low cost, NiTiHf is a favorite candidate for high-temperature applications [12]. However, NiTiHf alloys always exhibits a wide thermal hysteresis $\left(>50^{\circ} \mathrm{C}\right)$ in previous reports, which is not beneficial to fast actuation applications (such as MEMSs and robotics) $[12,13]$. Thus, quaternary NiTiHf-based alloys such as NiTiHfTa are designed for tuning the phase transformation behaviors and the mechanical properties through structural modifications. However, the thermal hysteresis of $\mathrm{Ni}_{49} \mathrm{Ti}_{36} \mathrm{Hf}_{15-x} \mathrm{Ta}_{x}(x=0,3,6,9,12)$ alloys is still wide, from 50.0 to $80.8^{\circ} \mathrm{C}$ [14].

Rare earth (RE) elements such as Ce [15], Gd [16], Dy [17], Nd [18], La [19] and $\operatorname{Pr}$ [20] have also been added to binary NiTi alloys to tune the phase transformation properties. The addition of $\mathrm{Ce}, \mathrm{Gd}$, and Dy to NiTi alloy increased the phase transformation temperatures because of some

$\triangle$ Shilei Zhao, shileizhao@btmc.edu.cn | ${ }^{1}$ School of Materials Science and Hydrogen Energy, Foshan University, Foshan 528000 , China. ${ }^{2}$ Baotou Medical College, Baotou 014040, China. ${ }^{3}$ College of Science, Inner Mongolia University of Technology, Hohhot 010051 , China. 
new-type second precipitates that exist in the NiTiRE alloys, which change the $\mathrm{Ni} / \mathrm{Ti}$ ratio of the matrix [21]. However, the La or Pr addition to NiTi alloy decreased the phase transformation temperatures because of stress around NiLa or NiPr precipitates, which provides resistance to martensite transformation $[19,20]$. Recently, the influence of $Y$ addition on the structure, the phase transformation, and the mechanical properties of NiTiHf alloys have been systematically investigated [22]. The $Y$ addition only slightly decreases the phase transformation temperatures, whereas the thermal hysteresis is still wide and remains almost constant at $\sim 50^{\circ} \mathrm{C}$ when the $Y$ content changes. $\mathrm{Nd}$ is another widely applied RE element, such as in glassy laser materials. However, no studies have been conducted on the $\mathrm{Nd}$ addition to NiTiHf alloy. Therefore, the influence of $\mathrm{Nd}$ addition on the structure, the phase transformation, and the mechanical properties of $\mathrm{NiTiHf}$ alloys remains unclear.

In this work, quaternary NiTiHfNd alloys with Nd content of $0,1,2$ at.\% were fabricated via arc melting, and the structure, phase transformation behavior, and the hardness were studied experimentally following our previously published studies [18-20]. It is found that $\mathrm{Nd}$ addition obviously decreases the martensitic transformation temperature of NiTiHf alloys but still maintains a relatively narrow thermal hysteresis and a relatively high Vickers hardness compared with most other components of NiTiHf-based alloys.

\section{Materials and methods}

NiTiHfNd alloys were fabricated by melting $50 \mathrm{~g}$ of raw materials ( 99.9 mass\% Ti, 99.7 mass\% Ni, 99.9 mass\% Hf, and 99.95 mass\% Nd) with predetermined nominal compositions in a vacuum non-consumable arc melting furnace by using a water-cooled copper crucible. The NiTi$\mathrm{HfNd}$ alloys are denoted by $\mathrm{Ni}_{50} \mathrm{Ti}_{29} \mathrm{Hf}_{21-x} \mathrm{Nd}_{x}(x=0,1,2)$ and $\mathrm{Ni}_{50} \mathrm{Ti}_{29-x} \mathrm{Hf}_{21} \mathrm{Nd}_{x}(x=1,2)$, respectively. Arc melting was repeated four times to ensure the uniformity of the composition. The as-fabricated alloys were spark-cut from the ingots and solution-treated at $850{ }^{\circ} \mathrm{C}$ for one hour in a vacuum quartz tube furnace. Thereafter, the specimens were mechanically and lightly polished to obtain a plain surface for the structure, phase transformation, and hardness tests.

The structure and chemical composition of NiTiHfNd alloys were examined using a scanning electron microscope (SEM, TM3030, Hitachi, Tokyo, Japan) equipped with an energy dispersive X-ray spectroscope (EDS, SwiftED3000, Oxford Instruments, Oxford, UK). All SEM images were taken at $15 \mathrm{kV}$ in backscattering mode. The phase transformation behaviors of NiTiHfNd alloys were measured using a differential scanning calorimeter (DSC, Q2000, TA Instrument, New Castle, USA) with a temperature range of $0-500{ }^{\circ} \mathrm{C}$ and a heating and cooling rate of $10^{\circ} \mathrm{C} / \mathrm{min}$. The mass of each sample for the DSC measurement was about $10 \mathrm{mg}$. The hardness of NiTiHfNd alloys was tested using a Vickers hardness tester (HXD-1000TMC) LCD, Shanghai Optical Instrument, Shanghai, China) with a loading of $200 \mathrm{~g}$ and a holding of $15 \mathrm{~s}$ for each indentation. The values of hardness are the average of at least 10 measurements for each sample.

\section{Results and discussion}

The morphologies of NiTiHfNd alloys are observed using SEM and the backscattering SEM images are depicted in Fig. 1. For NiTiHf alloy without Nd, the SEM image (Fig. 1a) shows a featureless morphology and no precipitate can be found, indicating a pure NiTiHf alloy. For NiTiHfNd alloys, the SEM images (Fig. 1b-e) clearly show precipitates (dark particles, marked by white arrows) and grey matrix morphologies. Obviously, the quantities and size of the precipitates increase with the increase in $\mathrm{Nd}$ content, as indicated by a comparison of Fig. 1b, d with Fig. 1c, e. To identify the chemical compositions of the precipitates and the matrix, EDS was employed and obtained data are summarized in Table 1 . The ratio of $\mathrm{Ni} / \mathrm{Ti} / \mathrm{Hf}$ in the matrix of each alloy is very close to each other and close to 50:29:21, which means the $\mathrm{Nd}$ addition almost does not affect the chemical composition of the matrix. This result confirms that the solid solubility limit of $\mathrm{Nd}$ in the matrix is very low, which should be attributed to the large atom size of $\mathrm{Nd}$ [22], whereas the ratio of $\mathrm{Nd} / \mathrm{Ni} / \mathrm{Ti} / \mathrm{Hf}$ in the precipitates of each alloy is about 82:10:5:3, which can be regarded as Nd-rich precipitates. Thus, EDS data can confirm that the matrix of NiTiHfNd alloys is ternary NiTiHf, whereas the precipitates are $\mathrm{Nd}$-rich precipitates with $\mathrm{Ni}, \mathrm{Ti}, \mathrm{Hf}$ solute. This structure is very similar to that of NiTiHfTa [14] and NiTiHfY [22] alloys. But this structure is very different from ternary NiTiLa [19] or NiTiPr [20] alloys, which consist of the $\mathrm{NiTi}$ matrix and near-equiatomic NiLa or NiPr precipitates.

The phase transformation behaviors of NiTiHfNd alloys are examined using DSC and the DSC curves are depicted in Fig. 2. Each DSC curve shows only one peak during heating and cooling, which indicates a one-step B2 $\leftrightarrow$ B19' phase transformation $[2,12]$. This phase transformation behavior is in agreement with ternary NiTiCu [5], NiTiTa [7], NiTiPd [11], NiTiCe [15], NiTiDy [17] as well as quaternary NiTiHfTa [14] and NiTiHfY [22] alloys. The martensitic transformation start temperature $\left(M_{s}\right)$, the martensitic transformation finish temperature $\left(M_{\mathrm{f}}\right)$, the austenite transformation start temperature $\left(A_{s}\right)$, and the austenite transformation finish temperature $\left(A_{\mathrm{f}}\right)$ were 


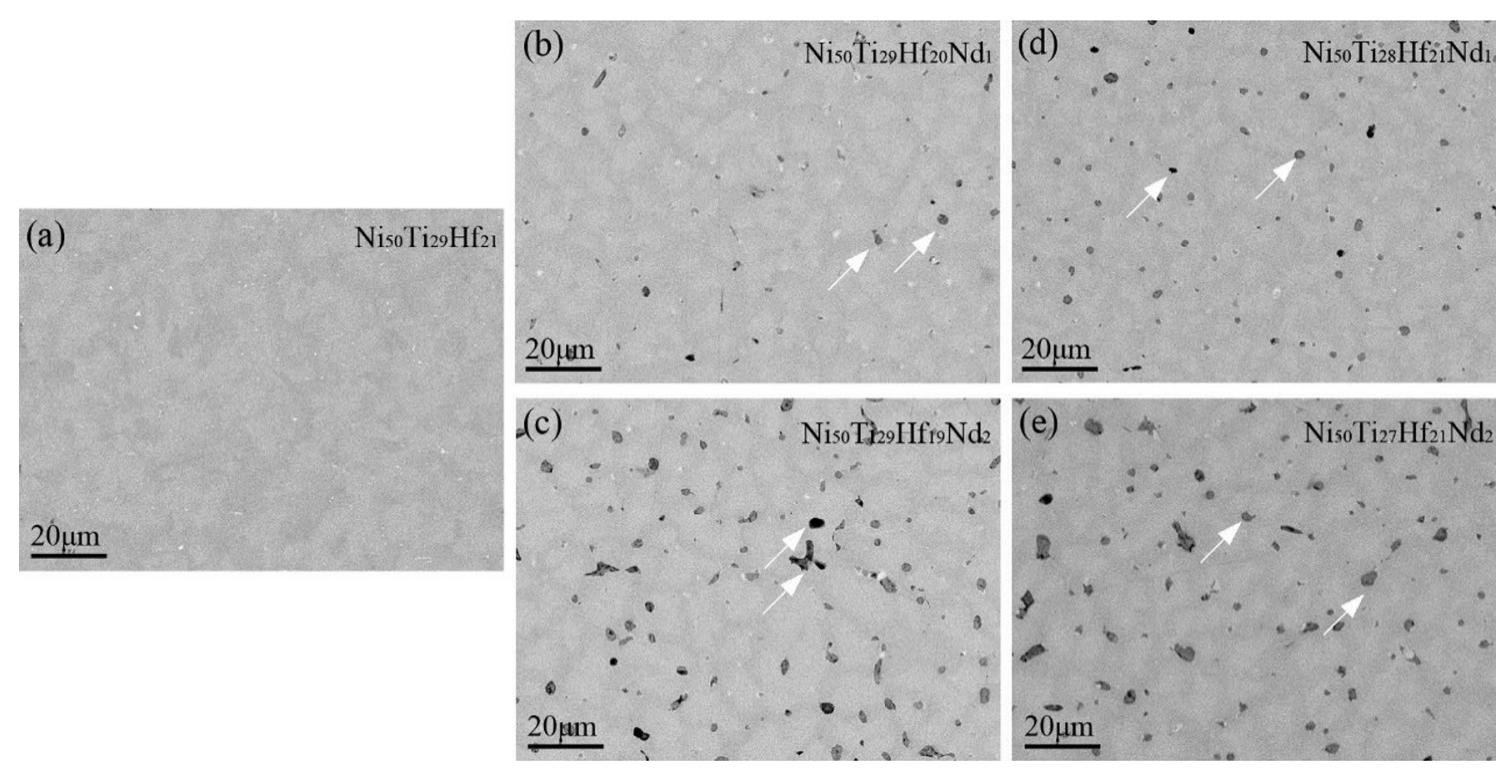

Fig. 1 Backscattering SEM images of NiTiHfNd alloys: a Ni $\mathrm{Ni}_{50} \mathrm{Ti}_{29} \mathrm{Hf}_{21}, \mathbf{b} \mathrm{Ni}_{50} \mathrm{Ti}_{29} \mathrm{Hf}_{20} \mathrm{Nd}_{1}, \mathbf{c ~ N i}_{50} \mathrm{Ti}_{29} \mathrm{Hf}_{19} \mathrm{Nd}_{2}, \mathbf{d ~ N i} \mathrm{Ni}_{50} \mathrm{Ti}_{28} \mathrm{Hf}_{21} \mathrm{Nd}_{1}, \mathbf{e} \mathrm{Ni}_{50} \mathrm{Ti}_{27} \mathrm{Hf}_{21} \mathrm{Nd}_{2}$

Table 1 Chemical compositions of NiTiHfNd alloys

\begin{tabular}{llrrrl}
\hline Alloys & Phase & $\mathrm{Ni}$ (at.\%) & $\mathrm{Ti}$ (at.\%) & $\mathrm{Hf}$ (at.\%) & $\mathrm{Nd}$ (at.\%) \\
\hline $\mathrm{Ni}_{50} \mathrm{Ti}_{29} \mathrm{Hf}_{21}$ & Matrix & 49.2 & 29.6 & 21.2 & - \\
$\mathrm{Ni}_{50} \mathrm{Ti}_{29} \mathrm{H}-$ & Matrix & 49.5 & 29.2 & 21.3 & 0 \\
$\mathrm{f}_{20} \mathrm{Nd}_{1}$ & Precipitates & 8.6 & 4.2 & 3.5 & 83.7 \\
$\mathrm{Ni}_{50} \mathrm{Ti}_{29} \mathrm{H}-$ & Matrix & 49.5 & 29.6 & 20.9 & 0 \\
$\mathrm{f}_{19} \mathrm{Nd}_{2}$ & Precipitates & 10.5 & 4.6 & 3.0 & 81.9 \\
$\mathrm{Ni}_{50} \mathrm{Ti}_{28} \mathrm{H}-$ & Matrix & 49.6 & 29.2 & 21.2 & 0 \\
$\mathrm{f}_{21} \mathrm{Nd}_{1}$ & Precipitates & 10.8 & 4.5 & 3.8 & 80.9 \\
$\mathrm{Ni}_{50} \mathrm{Ti}_{27} \mathrm{H}-$ & Matrix & 49.6 & 29.1 & 21.3 & 0 \\
$\mathrm{f}_{21} \mathrm{Nd}_{2}$ & Precipitates & 9.3 & 4.6 & 3.2 & 82.9 \\
\hline
\end{tabular}

determined from the DSC curves by tangent-intersection method (shown in Fig. 2), and are summarized in Table 2. Meanwhile, the martensitic transformation peak temperature $\left(M_{\mathrm{p}}\right)$, the austenite transformation peak temperature $\left(A_{\mathrm{p}}\right)$ and some literature data are summarized in Table 2 in comparison with this work. The $M_{s}$ of $\mathrm{Ni}_{50} \mathrm{Ti}_{29} \mathrm{Hf}_{21}$ alloy reaches as high as $314.1^{\circ} \mathrm{C}$, which is the highest $M_{\mathrm{s}}$ for $\mathrm{NiTiHf}$-based and NiTi alloys shown in Table 2. However, the $\mathrm{Nd}$ addition obviously decreases the transformation temperatures of NiTiHf alloys. For $\mathrm{Ni}_{50} \mathrm{Ti}_{29-x} \mathrm{Hf}_{21} \mathrm{Nd}_{x}(x=$ $1,2)$ alloys, the $M_{\mathrm{s}}$ is, respectively, decreased by $81.8^{\circ} \mathrm{C}$ (-26.0\%) for $\mathrm{Ni}_{50} \mathrm{Ti}_{28} \mathrm{Hf}_{21} \mathrm{Nd}_{1}$ and $121.3^{\circ} \mathrm{C}(-38.6 \%)$ for $\mathrm{Ni}_{50} \mathrm{Ti}_{27} \mathrm{Hf}_{21} \mathrm{Nd}_{2}$ compared with that of $\mathrm{Ni}_{50} \mathrm{Ti}_{29} \mathrm{Hf}_{21}$ alloy. Meanwhile, for $\mathrm{Ni}_{50} \mathrm{Ti}_{29} \mathrm{Hf}_{21-x} \mathrm{Nd}_{x}(x=1,2)$ alloys, the $M_{\mathrm{s}}$ is, respectively, decreased by $112.9^{\circ} \mathrm{C}(-35.9 \%)$ for $\mathrm{Ni}_{50} \mathrm{Ti}_{29} \mathrm{Hf}_{20} \mathrm{Nd}_{1}$ and $163.7^{\circ} \mathrm{C}(-52.1 \%)$ for $\mathrm{Ni}_{50} \mathrm{Ti}_{29} \mathrm{Hf}_{19} \mathrm{Nd}_{2}$ compared with that of $\mathrm{Ni}_{50} \mathrm{Ti}_{29} \mathrm{Hf}_{21}$ alloy. Obviously, the rate of descent of $M_{s}$ of $\mathrm{Ni}_{50} \mathrm{Ti}_{29} \mathrm{Hf}_{21-x} \mathrm{Nd}_{x}(x=1,2)$ is faster

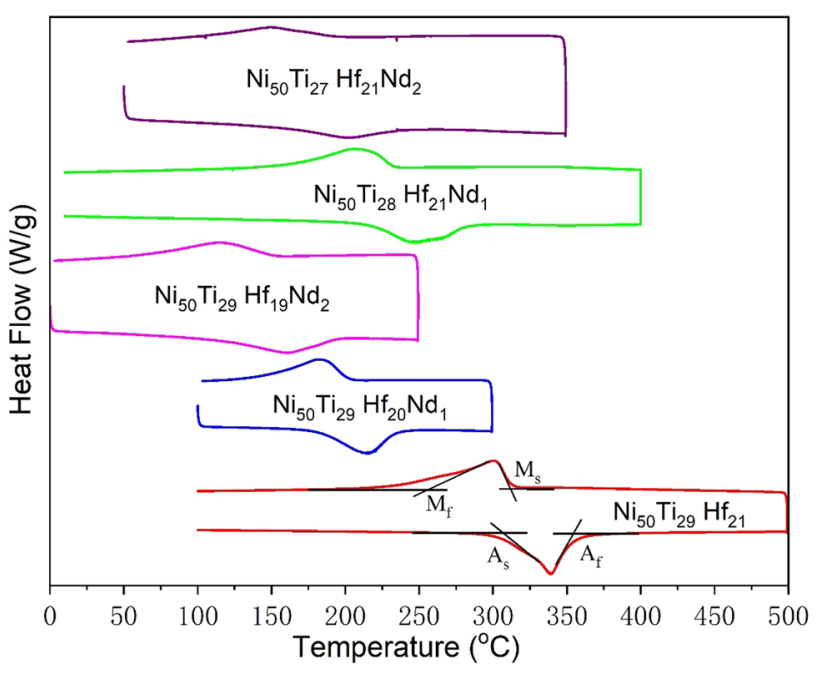

Fig. 2 DSC curves of NiTiHfNd alloys. Tangent lines are added to the $\mathrm{Ni}_{50} \mathrm{Ti}_{29} \mathrm{Hf}_{21}$ curve to show how the austenite and martensite transformation start and finish temperatures are determined

than that of $\mathrm{Ni}_{50} \mathrm{Ti}_{29-x} \mathrm{Hf}_{21} \mathrm{Nd}_{x}(x=1,2)$, which indicates that $\mathrm{Hf}$ content is more sensitive than Ti content for the $M_{\mathrm{s}}$ of NiTiHf-based alloys [2]. The $M_{\mathrm{s}}$ of $\mathrm{Ni}_{50} \mathrm{Ti}_{29-x} \mathrm{Hf}_{21} \mathrm{Nd}_{x}$ is higher than that of $\mathrm{Ni}_{50} \mathrm{Ti}_{29} \mathrm{Hf}_{21-x} \mathrm{Nd}_{x}$ at same $\mathrm{Nd}$ content because of higher $\mathrm{Hf}$ content. The thermal hysteresis $\left(H_{\mathrm{M}}\right)$ of the $\mathrm{Ni}_{50} \mathrm{Ti}_{29} \mathrm{Hf}_{21}$ alloy $\left(37.7^{\circ} \mathrm{C}\right)$ is notably narrower than that of most NiTiHf-based alloys as shown in Table 2. This result confirms a decreased tendency with the increase in $\mathrm{Hf}$ content when $\mathrm{Hf}$ content is above 10 at.\% for ternary NiTiHf alloys [12]. The Nd addition generally demonstrates an increasing tendency for the $H_{\mathrm{M}}$ of 
Table 2 Phase transformation temperatures and thermal hysteresis of NiTiHfNd and some literature data

\begin{tabular}{llllllllll}
\hline Alloys & $M_{\mathrm{s}}\left({ }^{\circ} \mathrm{C}\right)$ & $M_{\mathrm{f}}\left({ }^{\circ} \mathrm{C}\right)$ & $A_{\mathrm{s}}\left({ }^{\circ} \mathrm{C}\right)$ & $A_{\mathrm{f}}\left({ }^{\circ} \mathrm{C}\right)$ & $M_{\mathrm{p}}\left({ }^{\circ} \mathrm{C}\right)$ & $A_{\mathrm{p}}\left({ }^{\circ} \mathrm{C}\right)$ & $H_{\mathrm{M}}\left({ }^{\circ} \mathrm{C}\right)$ & Hardness (HV) & References \\
\hline $\mathrm{Ni}_{50} \mathrm{Ti}_{29} \mathrm{Hf}_{21}$ & $314.1 \pm 0.2$ & $253.9 \pm 0.3$ & $306.6 \pm 0.3$ & $358.8 \pm 0.3$ & $301.1 \pm 0.1$ & $338.8 \pm 0.2$ & 37.7 & $500.3 \pm 0.2$ & This work \\
$\mathrm{Ni}_{50} \mathrm{Ti}_{28} \mathrm{Hf}_{21} \mathrm{Nd}_{1}$ & $232.3 \pm 0.2$ & $164.4 \pm 0.2$ & $208.5 \pm 0.3$ & $282.5 \pm 0.3$ & $206.4 \pm 0.1$ & $247.1 \pm 0.2$ & 40.7 & $498.1 \pm 0.2$ & This work \\
$\mathrm{Ni}_{50} \mathrm{Ti}_{27} \mathrm{Hf}_{21} \mathrm{Nd}_{2}$ & $192.8 \pm 0.3$ & $83.6 \pm 0.4$ & $148.9 \pm 0.2$ & $235.1 \pm 0.2$ & $149.1 \pm 0.2$ & $200.7 \pm 0.1$ & 51.6 & $480.6 \pm 0.4$ & This work \\
$\mathrm{Ni}_{50} \mathrm{Ti}_{29} \mathrm{Hf}_{20} \mathrm{Nd}_{1}$ & $201.2 \pm 0.3$ & $146.5 \pm 0.3$ & $180.9 \pm 0.3$ & $233.2 \pm 0.2$ & $181.9 \pm 0.1$ & $216.1 \pm 0.2$ & 34.2 & $493.2 \pm 0.2$ & This work \\
$\mathrm{Ni}_{50} \mathrm{Ti}_{29} \mathrm{Hf}_{19} \mathrm{Nd}_{2}$ & $150.4 \pm 0.2$ & $65.3 \pm 0.3$ & $105.5 \pm 0.3$ & $195.2 \pm 0.3$ & $114.2 \pm 0.1$ & $160.7 \pm 0.2$ & 46.5 & $477.4 \pm 0.3$ & This work \\
$\mathrm{Ni}_{50.3} \mathrm{Ti}_{49.7}$ & 20.8 & -0.8 & 32.8 & 54.9 & 9.4 & 47.6 & 38.2 & 261 & {$[24]$} \\
$\mathrm{Ni}_{49.8} \mathrm{Ti}_{42.2} \mathrm{Hf}_{8}$ & 110.9 & 82.8 & 144.9 & 175.2 & 93.5 & 167.7 & 74.2 & - & - \\
$\mathrm{Ni}_{50} \mathrm{Ti}_{40} \mathrm{Hf}_{10}$ & 120 & - & 165 & - & - & - & 65 & - & {$[25]$} \\
$\mathrm{Ni}_{49.8} \mathrm{Ti}_{40.2} \mathrm{Hf}_{10}$ & 127.9 & 104.6 & 165.3 & 191.7 & 119.1 & 182.5 & 63.4 & - & {$[3]$} \\
$\mathrm{Ni}_{49.4} \mathrm{Ti}_{38.6} \mathrm{Hf}_{12}$ & 195 & 100 & 180 & 247 & - & - & 52 & - & {$[25]$} \\
$\mathrm{Ni}_{49.8} \mathrm{Ti}_{35.2} \mathrm{Hf}_{15}$ & 206.8 & 177.9 & 238.9 & 257.8 & 194.9 & 252.9 & 58 & - & {$[26]$} \\
$\mathrm{Ni}_{50} \mathrm{Ti}_{30} \mathrm{Hf}_{20}$ & 290 & - & 317 & - & - & - & 60 & - & {$[25]$} \\
$\mathrm{Ni}_{49.8} \mathrm{Ti}_{30.2} \mathrm{Hf}_{20}$ & 299.9 & 273.3 & 322.7 & 337.5 & 290.5 & 331.5 & 41 & - & {$[3]$} \\
$\mathrm{Ni}_{50.3} \mathrm{Ti}_{29.7} \mathrm{Hf}_{20}$ & 146.4 & 116.6 & 160.4 & 177.5 & 177.4 & 209.4 & 32 & 406 & {$[25]$} \\
$\mathrm{Ni}_{50.3} \mathrm{Ti}_{24.7} \mathrm{Hf}_{25}$ & 252.3 & 220.1 & 264.1 & 288.8 & 244.3 & 280.9 & 36.6 & 425 \\
$\mathrm{Ni}_{49} \mathrm{Ti}_{36} \mathrm{Hf}_{12} \mathrm{Ta}_{3}$ & - & - & - & - & 177.6 & 228.6 & 51 & - \\
$\left(\mathrm{Ni}_{49} \mathrm{Ti}_{36} \mathrm{Hf}_{15}\right)_{98} \mathrm{Y}$ & - & - & - & - & 189.9 & 239.0 & 49.1 & 388.9 \\
\hline
\end{tabular}

NiTiHf alloys. For $\mathrm{Ni}_{50} \mathrm{Ti}_{29-x} \mathrm{Hf}_{21} \mathrm{Nd}_{x}(x=1,2)$ alloys, the $H_{\mathrm{M}}$ is, respectively, increased by $3{ }^{\circ} \mathrm{C}\left(8.0 \%, \mathrm{Ni}_{50} \mathrm{Ti}_{28} \mathrm{Hf}_{21} \mathrm{Nd}_{1}\right)$ and $13.9{ }^{\circ} \mathrm{C}\left(36.9 \%, \mathrm{Ni}_{50} \mathrm{Ti}_{27} \mathrm{Hf}_{21} \mathrm{Nd}_{2}\right)$ compared with that of $\mathrm{Ni}_{50} \mathrm{Ti}_{29} \mathrm{Hf}_{21}$ alloy. Meanwhile, for $\mathrm{Ni}_{50} \mathrm{Ti}_{29} \mathrm{Hf}_{21-x} \mathrm{Nd}_{x}(x=1,2)$ alloys, the $H_{M}$ is, respectively, increased by $-3.5^{\circ} \mathrm{C}(-9.3 \%$, $\left.\mathrm{Ni}_{50} \mathrm{Ti}_{29} \mathrm{Hf}_{20} \mathrm{Nd}_{1}\right)$ and $8.8{ }^{\circ} \mathrm{C}\left(23.3 \%, \mathrm{Ni}_{50} \mathrm{Ti}_{29} \mathrm{Hf}_{19} \mathrm{Nd}_{2}\right)$ compared with that of $\mathrm{Ni}_{50} \mathrm{Ti}_{29} \mathrm{Hf}_{21}$ alloy. Obviously, the rate of increase in $H_{M}$ of $\mathrm{Ni}_{50} \mathrm{Ti}_{29-x} \mathrm{Hf}_{21} \mathrm{Nd}_{x}(x=1,2)$ is faster than that of $\mathrm{Ni}_{50} \mathrm{Ti}_{29} \mathrm{Hf}_{21-x} \mathrm{Nd}_{x}(x=1,2)$, which implies that $\mathrm{Ti}$ content is more sensitive than $\mathrm{Hf}$ content for the $\mathrm{H}_{M}$ of $\mathrm{NiTiHf}$-based alloys.

It is well known that the phase transformation temperatures are strongly dependent on $\mathrm{Ni}$ content in binary $\mathrm{NiTi}$ alloy when Ni content is higher than 50 at.\% [23]. Previous reports show that the addition of $\mathrm{Hf}$ content above 10 at.\% almost linearly increases the $M_{\mathrm{s}}$ of NiTi alloys at a rate of over $20^{\circ} \mathrm{C} /$ at. $\% \mathrm{Hf}$, when $\mathrm{Ni}$ content is not higher than 50 at.\% [12,24], also as shown in Table 2. Meanwhile, the $M_{s}$ is not notably affected by a change in Ni content for NiTiHf alloys, but it dropped steeply when Ni content increased beyond the equiatomic (50 at.\%) composition [12]. Previous reports showed that the addition of RE element in NiTi alloy has evident effects on the martensitic transformation, which is because of either the change of the $\mathrm{Ni} / \mathrm{Ti}$ ratio of the matrix [15-17] or the stress around NiRE precipitates $[19,20]$. As shown in Table 1, Ni content in the matrix of $\mathrm{NiTiHfNd}$ alloys is very close to each other and not higher than 50 at.\%. Thus, the decrease in the $M_{\mathrm{s}}$ of NiTiHfNd alloys is not due to Ni content. Whereas, SEM observations (Fig. 1) suggest that the size and quantity of the $\mathrm{Nd}$-rich precipitates increased with the increase in $\mathrm{Nd}$ content. Thus, we propose that stress around Nd-rich precipitates is responsible for the decrease in the $M_{\mathrm{s}}$ with the increase in $\mathrm{Nd}$ content in NiTiHfNd alloys. While, increasing $\mathrm{Hf}$ contents improves the crystallographic compatibility and thus results in lower hysteresis widths [25].

Hardness that is closely related to material strength has been regarded as an indicative parameter of the mechanical properties of NiTi-based alloys [13, 22, 24, 27, 28]. Thus, the hardness value of NiTiHfNd alloys was measured and is shown in Fig. 3. The hardness value of $\mathrm{Ni}_{50} \mathrm{Ti}_{29} \mathrm{Hf}_{21}$ alloy is $500 \mathrm{HV}$, which is much larger than that (261 HV) of binary $\mathrm{Ni}_{50.3} \mathrm{Ti}_{49.7}$ alloy. This result can be explained by the solid solution being strengthened by bigger $\mathrm{Hf}$

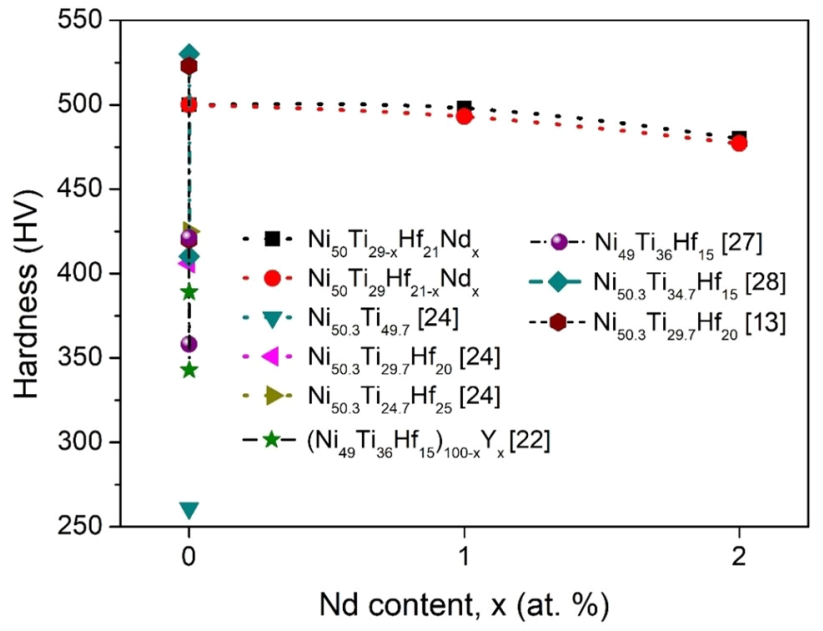

Fig. 3 Hardness of NiTiHfNd alloys and some literature data 
atoms, and the substitution of $\mathrm{Hf}$ against $\mathrm{Ti}$ in NiTiHfbased alloys leads to a linear increase in alloy hardness [24]. For $\mathrm{Ni}_{50} \mathrm{Ti}_{29-x} \mathrm{Hf}_{21} \mathrm{Nd}_{x}(x=1,2)$ alloys, the hardness decreased by $12 \mathrm{HV}\left(-2.4 \%, \mathrm{Ni}_{50} \mathrm{Ti}_{28} \mathrm{Hf}_{21} \mathrm{Nd}_{1}\right)$ and $20 \mathrm{HV}$ $\left(-4 \%, \mathrm{Ni}_{50} \mathrm{Ti}_{27} \mathrm{Hf}_{21} \mathrm{Nd}_{2}\right.$ ) compared with that of $\mathrm{Ni}_{50} \mathrm{Ti}_{29} \mathrm{Hf}_{21}$ alloy. Meanwhile, for $\mathrm{Ni}_{50} \mathrm{Ti}_{29} \mathrm{Hf}_{21-x} \mathrm{Nd}_{x}(x=1,2)$ alloys, the hardness decreased by $17 \mathrm{HV}\left(-3.4 \%, \mathrm{Ni}_{50} \mathrm{Ti}_{29} \mathrm{Hf}_{20} \mathrm{Nd}_{1}\right)$ and $23 \mathrm{HV}\left(-4.6 \%, \mathrm{Ni}_{50} \mathrm{Ti}_{29} \mathrm{Hf}_{19} \mathrm{Nd}_{2}\right)$ compared with that of $\mathrm{Ni}_{50} \mathrm{Ti}_{29} \mathrm{Hf}_{21}$ alloy. The hardness of $\mathrm{Ni}_{50} \mathrm{Ti}_{29-x} \mathrm{Hf}_{21} \mathrm{Nd}_{x}$ is higher than that of $\mathrm{Ni}_{50} \mathrm{Ti}_{29} \mathrm{Hf}_{21-x} \mathrm{Nd}_{x}$ at same $\mathrm{Nd}$ content because of higher $\mathrm{Hf}$ content. Previous reports demonstrated that the hardness of NiTiHf-based alloys can be influenced by Hf content [24], precipitates [13], thermal treatment [28], and quaternary alloying [22], as shown in Fig. 3. SEM observation (Fig. 1) confirms that the size of $\mathrm{Nd}$-rich precipitates increases with the increase in $\mathrm{Nd}$ content in NiTiHfNd alloys. Consequently, material strength, as observed from the hardness results, decreases with the increase in $\mathrm{Nd}$ content in NiTiHfNd alloys [13].

\section{Conclusions}

This work expands our previous studies on the ternary NiTiRE alloy to the quaternary NiTiHfRE alloy. The influence of the addition of RE element $\mathrm{Nd}$ on the structure, phase transformation behavior, and hardness of NiTiHf was investigated experimentally by SEM, DSC and Vickers hardness tester. The structure of the NiTiHfNd alloys consists of the $\mathrm{NiTiHf}$ matrix and Nd-rich precipitates. The NiTiHfNd alloy undergoes a one-step phase transformation during heating and cooling. $\mathrm{Ni}_{50} \mathrm{Ti}_{29} \mathrm{Hf}_{21}$ alloy demonstrates a martensitic transformation temperature as high as $314.1^{\circ} \mathrm{C}$, a thermal hysteresis as narrow as $37.7^{\circ} \mathrm{C}$, and a Vickers hardness as high as $500 \mathrm{HV}$. The martensitic transformation start temperature decreases gradually with the increase in $\mathrm{Nd}$ content due to stress around $\mathrm{Nd}$-rich precipitates provides resistance to the martensitic transformation. However, NiTiHfNd alloys still maintain a relatively narrow thermal hysteresis and relatively high Vickers hardness compared with most other components of NiTiHf-based high-temperature alloys.

Acknowledgements The authors acknowledge Dr. Y.J. Jin (IMUT) for help of DSC testing.

Funding The Natural Science Foundation of Inner Mongolia (Grant No. 2019BS03010).

\section{Declarations}

Conflict of interest The authors declare that they have no conflict of interest.
Open Access This article is licensed under a Creative Commons Attribution 4.0 International License, which permits use, sharing, adaptation, distribution and reproduction in any medium or format, as long as you give appropriate credit to the original author(s) and the source, provide a link to the Creative Commons licence, and indicate if changes were made. The images or other third party material in this article are included in the article's Creative Commons licence, unless indicated otherwise in a credit line to the material. If material is not included in the article's Creative Commons licence and your intended use is not permitted by statutory regulation or exceeds the permitted use, you will need to obtain permission directly from the copyright holder. To view a copy of this licence, visit http://creativecommons. org/licenses/by/4.0/.

\section{References}

1. Otsuka K, Ren X (1999) Recent developments in the research of shape memory alloys. Intermetallics 7:511-528

2. Otsuka K, Ren X (2005) Physical metallurgy of Ti-Ni-based shape memory alloys. Prog Mater Sci 50:511-678

3. Zarinejad M, Liu Y (2013) Dependence of the transformation temperatures of NiTi based shape memory alloys on the number and concentration of valence electrons. Adv Funct Mater 18:2789-2794

4. Frenzel J, Pfetzing J, Neuking K, Eggeler G (2008) On the influence of thermomechanical treatments on the microstructure and phase transformation behavior of $\mathrm{Ni}-\mathrm{Ti}-\mathrm{Fe}$ shape memory alloys. Mater Sci Eng A 482:635-638

5. Tomozawa M, Kim HY, Miyazaki S (2009) Shape memory behavior and internal structure of $\mathrm{Ti}-\mathrm{Ni}-\mathrm{Cu}$ shape memory alloy thin films and their application for microactuators. Acta Mater 57:441-452

6. Zheng YF, Zhao LC, Ye HQ (1999) High resolution electron microscopy studies on the interface structure of deformed stress induced martensite variants in a $\mathrm{Ti}-\mathrm{Ni}-\mathrm{Nb}$ shape memory alloy. Mater Sci Eng A 273-275:271-274

7. Gong CW, Wang YN, Yang DZ (2006) Phase transformation and second phases in ternary Ni-Ti-Ta shape memory alloys. Mater Chem Phys 96:183-187

8. Bertheville B (2005) Powder metallurgical processing of ternary $\mathrm{Ni}_{50} \mathrm{Ti}_{50-\mathrm{x}} \mathrm{Zr}_{\mathrm{x}}(\mathrm{x}=5,10$ at.\%) alloys. J Alloys Compd 398:94-99

9. Meng XL, Cai W, Fu YD, Li QF, Zhang JX, Zhao LC (2008) Shapememory behaviors in an aged Ni-rich TiNiHf high temperature shape-memory alloy. Intermetallics 16:698-705

10. Casalena L, Coughlin DR, Yang F (2015) Transformation and deformation characterization of NiTiHf and NiTiAu high temperature shape memory alloys. Microsc Microanal 21:607-608

11. Liu Y, Kohl M, Okutsu K, Miyazaki S (2004) A TiNiPd thin film microvalve for high temperature applications. Mater Sci Eng A 378:205-209

12. Ma J, Karaman I, Noebe RD (2010) High temperature shape memory alloys. Int Mater Rev 55:257-315

13. Karaca HE, Saghaian SM, Ded G, Tobe H, Basaran B, Maier HJ, Noebe RD, Chumlyakov YI (2013) Effects of nanoprecipitation on the shape memory and material properties of an Ni-rich $\mathrm{NiTiHf}$ high temperature shape memory alloy. Acta Mater 61:7422-7431

14. Prasad RVS, Park CH, Kim SW, Hong JK, Yeom JT (2017) Microstructure and phase transformation behavior of a new high temperature NiTiHf-Ta shape memory alloy with excellent formability. J Alloys Compd 697:55-61 
15. Cai W, Liu AL, Sui JH, Zhao LC (2006) Effects of cerium addition on martensitic transformation and microstructure of $\mathrm{Ti}_{49.3} \mathrm{Ni}_{50.7}$ alloy. Mater Trans 47:716-719

16. Liu AL, Cai W, Gao ZY, Zhao LC (2006) The microstructure and martensitic transformation of $\left(\mathrm{Ti}_{49.3} \mathrm{Ni}_{50.7}\right)_{1-x} \mathrm{Gd}_{\mathrm{x}}$ shape memory alloys. Mater Sci Eng A 438-440:634-638

17. Liu AL, Gao ZY, Gao L, Cai W, Wu Y (2007) Effect of Dy addition on the microstructure and martensitic transformation of a Nirich TiNi shape memory alloy. J Alloys Compd 437:339-343

18. Dovchinvanching $M$, Zhao CW, Zhao SL, Meng XK, Jin YJ, Xing YM (2014) Effect of Nd addition on the microstructure and martensitic transformation of $\mathrm{Ni}-\mathrm{Ti}$ shape memory alloys. Adv Mater Sci Eng 2014:489701

19. Zhao CW, Li WY, Zhao SL, Jin YJ, Meng XK, Hou QY (2017) Effect of La addition on the microstructure and martensitic transformation of Ni-Ti-La alloys. Vacuum 137:169-174

20. Zhao CW, Zhao SL, Jin YJ, Guo SQ, Hou QY (2017) Microstructure and martensitic transformation of $\mathrm{Ni}-\mathrm{Ti}-\mathrm{Pr}$ alloys. Appl Phys $\mathrm{A}$ 123:580

21. Cai W, Meng XL, Zhao LC (2005) Recent development of TiNibased shape memory alloys. Curr Opin Solid State Mater 9:296-302

22. Yi XY, Gao WH, Meng XL, Gao ZY, Cai W, Zhao LC (2017) Martensitic transformation behaviors and mechanical properties of $\left(\mathrm{Ti}_{36} \mathrm{Ni}_{49} \mathrm{Hf}_{15}\right)_{100-\mathrm{x}} \mathrm{Y}_{\mathrm{x}}$ high temperature shape memory alloys. J Alloys Compd 705:98-104

23. Frenzel J, George EP, Dlouhy A, Somsen C, Wagner MFX, Eggeler $\mathrm{G}$ (2010) Influence of $\mathrm{Ni}$ on martensitic phase transformations in NiTi shape memory alloys. Acta Mater 58:3444-3458
24. Prasher M, Sen D, Tewari R, Krishna PSR, Babu PD, Krishnan M (2020) Effect of Hf solute addition on the phase transformation behavior and hardness of a Ni-rich NiTi alloy. Mater Chem Phys 247:122890

25. Frenzel J, Wieczorek A, Opahle I, Maaß B, Drautz R, Eggeler G (2015) On the effect of alloy composition on martensite start temperatures and latent heats in $\mathrm{Ni}$-Ti-based shape memory alloys. Acta Mater 90:213-231

26. Suresh KS, Kim DI, Bhaumik SK, Suwas S (2014) Evolution and stability of phases in a high temperature shape memory alloy $\mathrm{Ni}_{49.4} \mathrm{Ti}_{38.6} \mathrm{Hf}_{12}$. Intermetallics 44:18-25

27. Yi X, Sun K, Gao W, Meng X, Cai W, Zhao L (2018) Martensitic transformation and mechanical properties of Ti-Ni-Hf high temperature shape memory alloy with network structure second particles. J Alloys Compd 735:1219-1226

28. Moshref-Javadi M, Seyedein SH, Salehi MT, Aboutalebi MR (2013) Age-induced multi-stage transformation in a Ni-rich NiTiHf alloy. Acta Mater 61:2583-2594

Publisher's note Springer Nature remains neutral with regard to jurisdictional claims in published maps and institutional affiliations. 